\title{
Hyperpigmented Nodular Dermatofibroma: Two Cases Report and Brief Literature Review
}

\author{
Andi Hardianty (D), Khairuddin Djawad*(D), Siswanto Wahab (D), Airin Nurdin (D) \\ Department of Dermatology and Venereology, Faculty of Medicine, Hasanuddin University, Makassar, South Sulawesi, \\ Indonesia
}

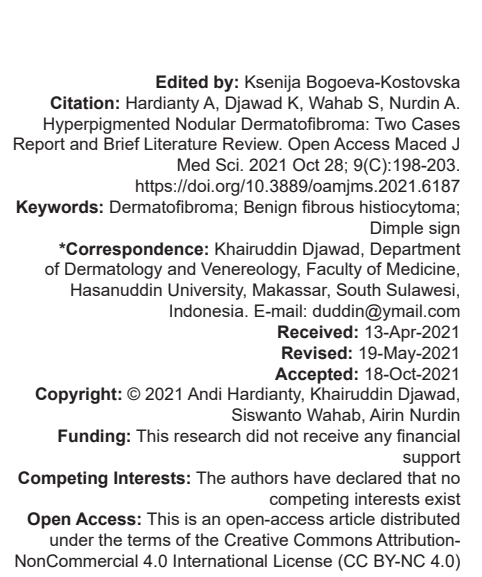

\section{Introduction}

Dermatofibroma (DF) also known as benign fibrous histiocytoma, sclerosing hemangioma, xanthogranuloma, fibroxanthoma, and nodular sub epidermal fibrosis, was first described by Dahli and it is considered as one of the most common benign tumors of the skin which is characterized by tumoral differentiations of fibroblasts and histiocytes with an unknown etiology. DF is commonly confined to the dermis or which extends into the superficial subcutaneous tissues [1]. These lesions are most common in adult's patients. Most studies indicate a female predominance [2].

DFs are small, firm, and raised skin growths, which may either be elevated or slightly depressed [3]. Nodular hyperpigmented is the typical DF that generally occurs as a single asymptomatic reddish-brown nodule measure few millimeters in diameter located most commonly at lower legs but can also appear on the arms or trunk [4]. DF exhibits dimpling when squeezed between fingers called "dimple sign" [5].

Most DFs are a cosmetic problem, and no treatment is urgency. Explaining the patient of the benign nature of the lesion is needed. If treatment is requested, surgical excision is the method of choice [6].

\section{Case Report 1}

A 27-year-old woman presented to the dermatology clinic with a small, firm, and pigmented raised skin growth on her right thigh that had been present for approximately 5 years. The lesion is single occasionally painless, it has recently increased in size gradually since 3 years and then became stable. There was no history of trauma preceding the onset of the lesion present. Physical examination revealed by a $0.5 \mathrm{~cm}$ hyperpigmented nodule, well demarcated, asymptomatic, and over medial aspect of the right lower limb. The lesions demonstrated dimpling when the skin lateral to them was pressed toward the lesion (Figure 1). Dermoscopic evaluation was also taken.

The dermoscopic patterns observed on the lesion were peripheral delicate pigment network and central homogenous pigmentation, multiple scar-like patch (Figure 2). 


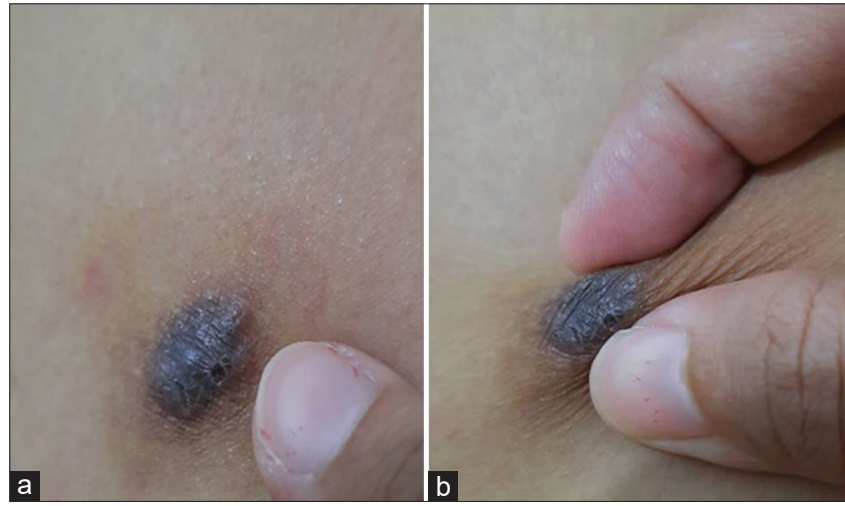

Figure 1: (a) A pigmented dermal nodule is shown on the right medial thigh. (b) Positive Dimple sign

Treatment plan of local excision was performed using an elliptical incision under local anesthesia and sample sent to pathology. The histological study revealed hyperplastic epidermis with hyperpigmentation of the basal layer. Proliferation of fibroblast includes spindle cells with a storiform arrangement in the dermis (Figure 3). Based on the morphologic features with positive dimple sign, dermoscopic evaluation, and histopathologic findings, diagnosis of DFs was made. The patient follow-up was performed after 14 days of local excision (Figure 4). The patient throughout the post-operative course had no complications and has a good result. There was no recurrence noted during the 6 months follow-up period.

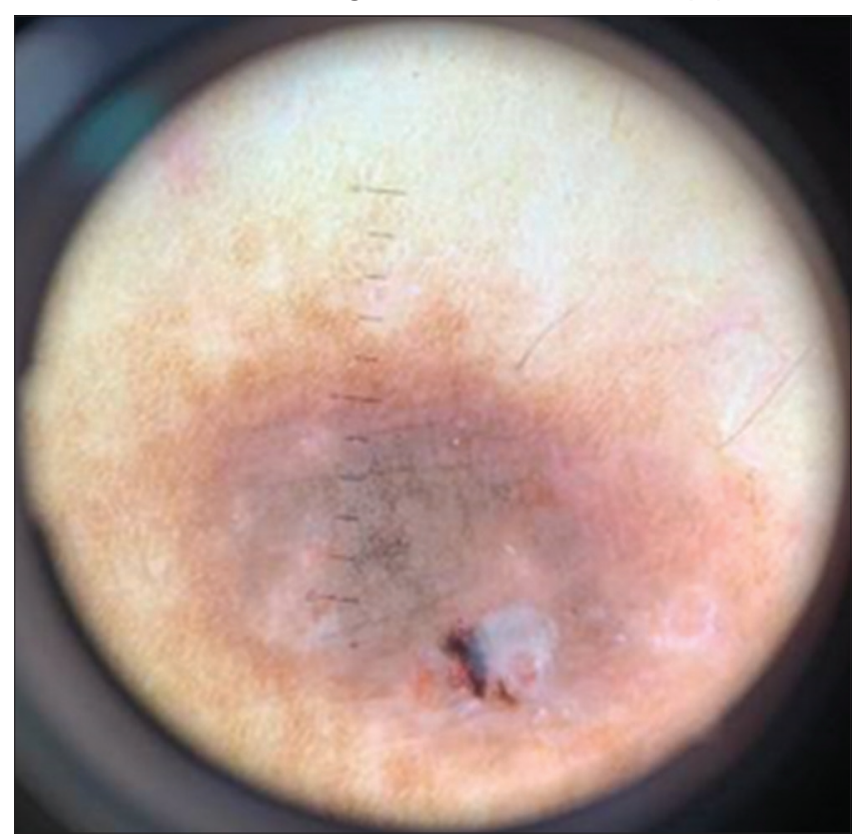

Figure 2: Peripheral delicate pigment network and central homogenous pigmentation, multiple scar-like patch

\section{Case Report 2}

A 23-year-old woman was admitted for a single pigmented lesion on her left lower leg that had been developing for 5 years. It had recently become enlarged

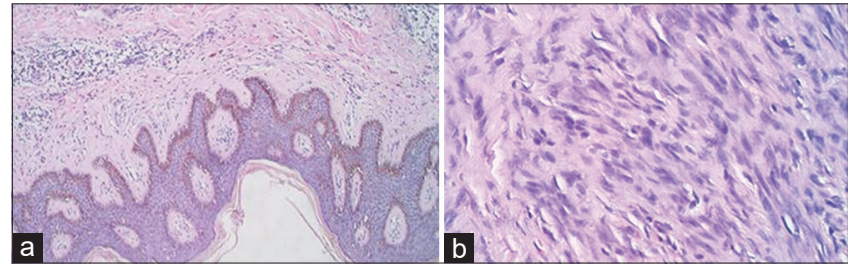

Figure 3: (a) Hyperplastic epidermis with hyperpigmentation of the basal layer (b) spindle cells had a fibrohistiocytic appearance in a storiform arrangement

since a year. The lesion was painless. She did not have any episode of local trauma or injection. Her past and family history was also unremarkable. Cutaneous examination showed a single hyperpigmented dermal nodule with $1 \mathrm{~cm}$ in size, asymptomatic, and smooth surface over medial aspect of the left leg (Figure 5). The dermoscopic patterns observed on the lesion were peripheral delicate pigment network and central homogenous pigmentation (Figure 6).

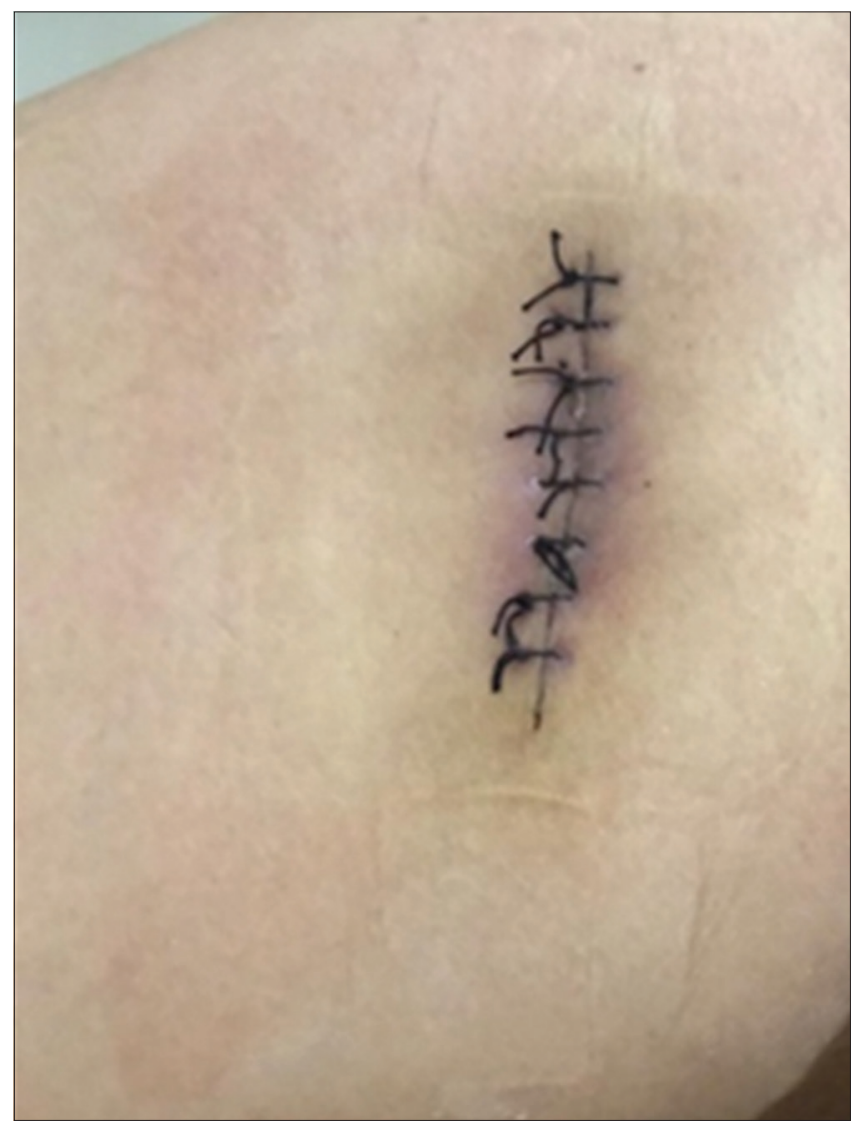

Figure 4: Follow-up after 14 days of local excision

The lesion was surgically excised under local anesthesia. A nodule was excised and sent to pathology. The histological study showed hyperplastic and hyperkeratotic epidermis. Proliferation of fibroblast includes spindle cells, atypic, with a storiform arrangement in the dermis (Figure 7). Based on the morphologic features, dermoscopic and histopathologic evaluation, diagnosis of DFs was established.

The patient follow-up was performed 7 days after surgical excision of dermal nodule (Figure 8). The lesion was completely removed and healed by primary intention. There was no tendency of recurrence at 6 months follow-up. 


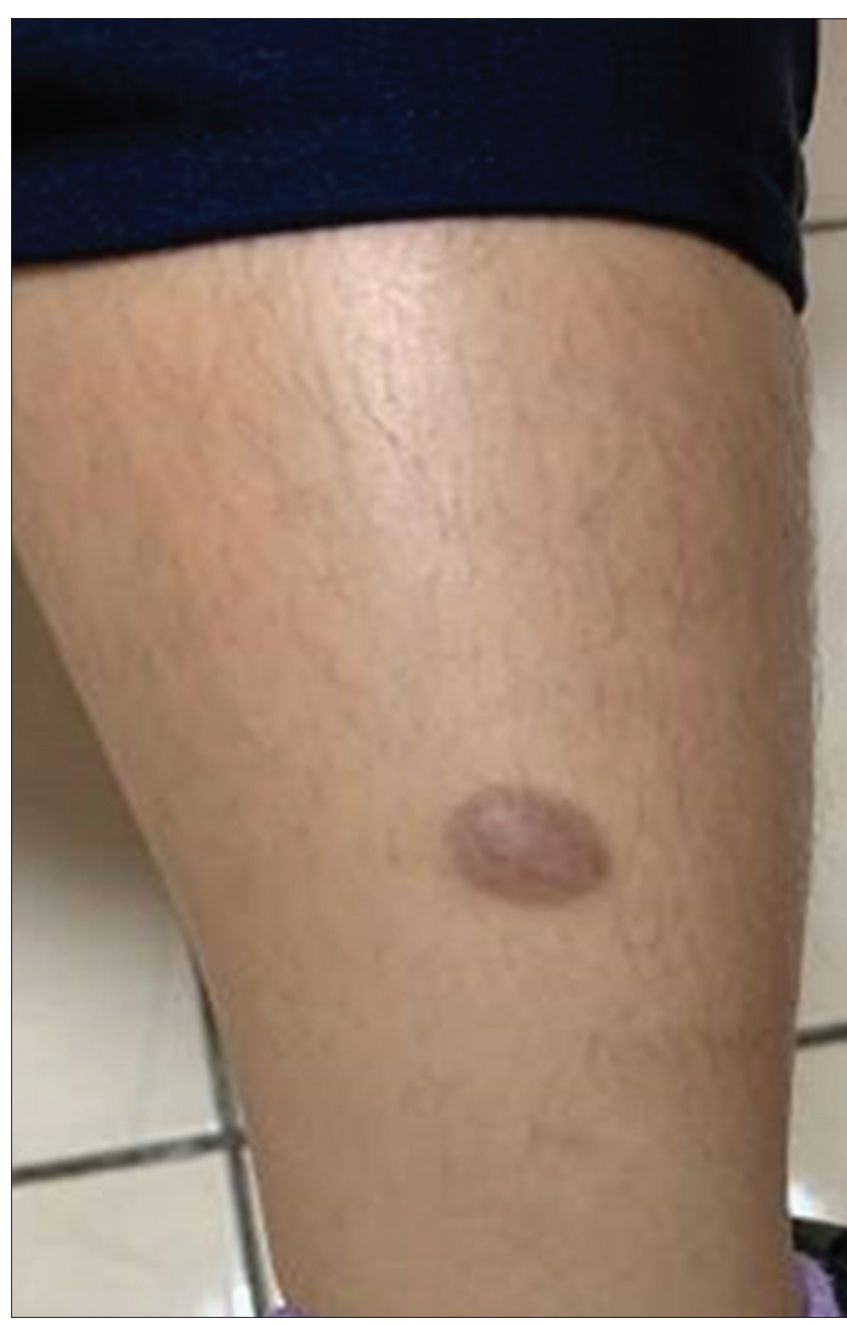

Figure 5: A single dermal nodule with smooth surface over medial aspect of the left lower leg

\section{Discussion}

Many dermal tumors originate from one of several cell types, including fibroblasts, endothelial cells, nerve cells, and smooth muscle cells. These tumors may reveal spindle cell morphology, and certain morphological clues are helpful in differentiating the cell type of origin, and thus providing an accurate diagnosis. DFs represent a proliferation of dermal fibroblasts, and are often classified as "fibrohistiocytic" because they may also display histiocytic differentiation in the form of foamy and/or giant cells [7]. Most DF occurs in young to middle-aged adults. Women are affected more frequently than men. DF may grow rapidly in a short period, then reach a maximal size and persist [2] DF mostly asymptomatic and painless. It can develop after a minor trauma or insect bite which predominately occurs in the lower extremities [8]. DFs seldom occur in children [9].

The etiology of DFs remains unclear. Patients who are diagnosed with DF often have a history of local trauma (such as an insect bite) or injection at the site of the lesion, but it only found in about a fifth of cases. More often,

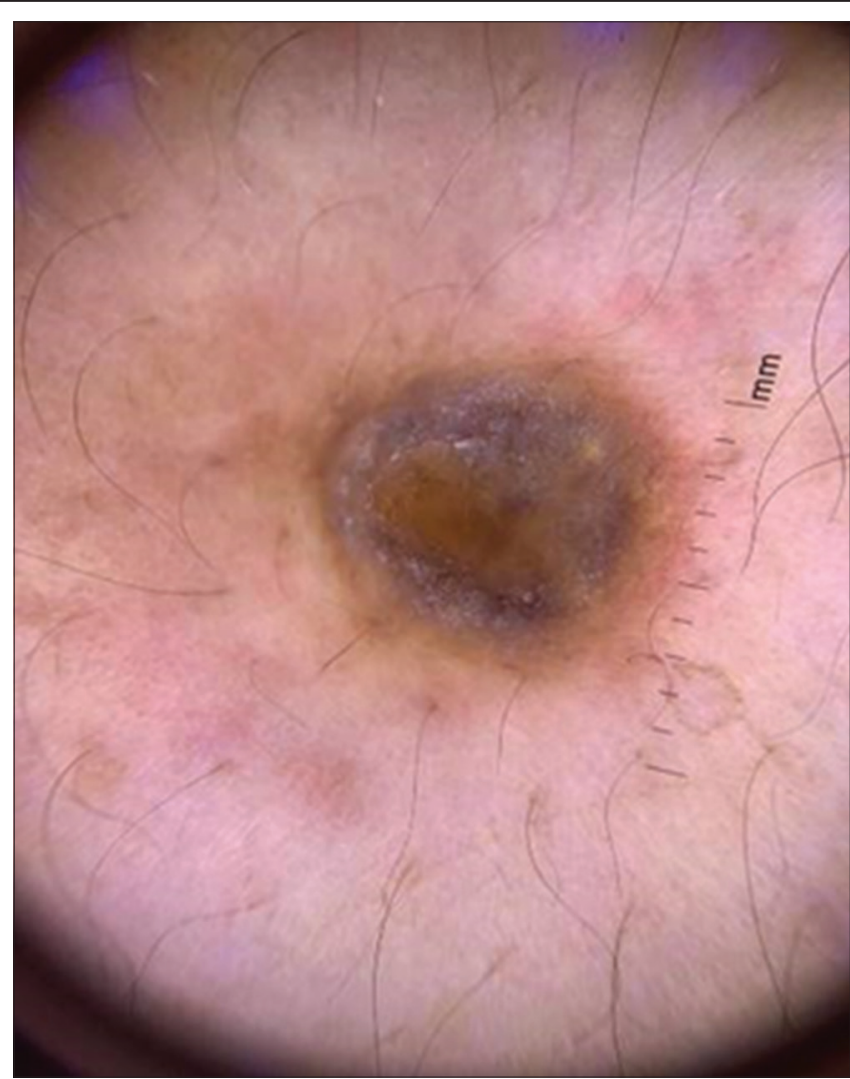

Figure 6: Dermoscopic findings. Peripheral delicate pigment network dan central homogenous pigmentation

there is no inciting event or trauma, and the DF develops spontaneously. Some investigators favor that DFs are a reactive process [10]. DF has widely variants, they are: (1) Hyperpigmented nodular DF; (2) non-pigmented DF; (3) Delled ("atrophic") DF; (4) Giant DF; (5) subcutaneous DF; (6) multiple grouped DFs; (7) disseminated multiple DFs; (8) unusual locations for DFs: Face, finger, subungual, palmoplantar, and scalp;(9) ankle-type DF (lipidized fibrous histiocytoma); (10) erosive and ulcerated DF; (11) pedunculated or polypoid DF; (12) hyperkeratotic DF; (13) annular hemosiderotic DF; (14) multinodular hemosiderotic DF; and (15) DF with satellitosis.

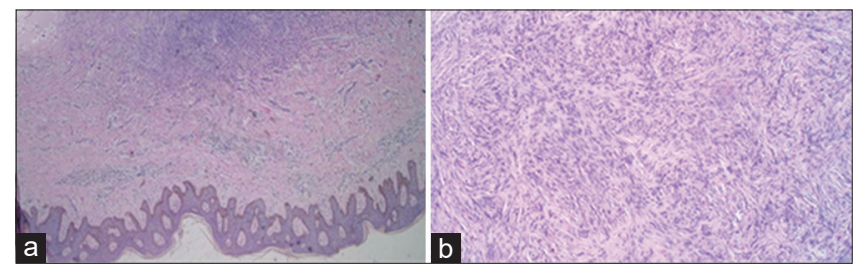

Figure 7: (a) Hyperplastic epidermis (b) proliferation of fibroblast like spindle cells, atypic, with a storiform arrangement in the dermis

Nodular hyperpigmented is one of the common clinical variants of DF [11]. It generally occurs as solitary reddish-brown nodules. They are firm, hyperpigmented, slightly scaly, and minimally elevated to dome-shaped ranging from a few millimeters to $1 \mathrm{~cm}$ and are up to $2 \mathrm{~cm}$ in size [11]. Although giant lesions $>5 \mathrm{~cm}$ occur [9], giant DF is one of the most striking and uncommon clinical variants of DF [4]. The presence of multiple DFs is rare [12]. However, multiple DF can be 


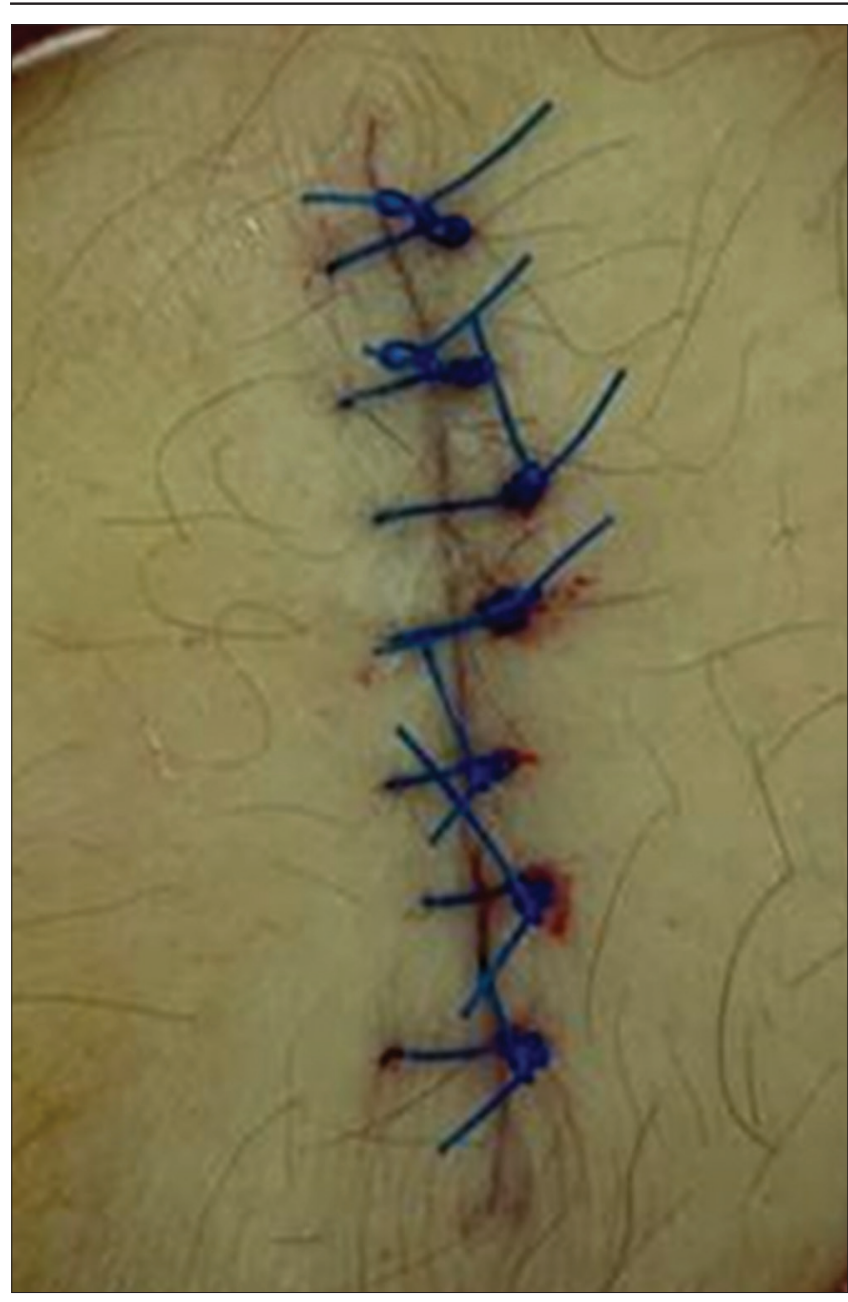

Figure 8: Follow-up after 7 days of surgical excision

associated with various conditions [13]. Multiple lesions are found in patients with both normal and immune function disorders including physiologic changes of pregnancy, immunodeficiencies such as HIV [14], and autoimmune diseases such as systemic lupus erythematosus [15], myasthenia gravis, pemphigus vulgaris [14], and atopic dermatitis [16]. DFs most often found in the lower extremities, but the tumor can manifest at any site. When lateral inward pressure of the skin produces a central dimpling over the lesion, the lesions become depressed skin called dimple sign or Fitzpatrick's sign [15].

DF is usually easy to diagnose. However, a DF may show a wide variety of variants, atypical case, and for differentiate DF that may mimic other skin tumors including malignant melanoma. Therefore, the diagnosis may be difficult and it is important to use non-invasive diagnostic tools, especially dermoscopy. The dermoscopic patterns in DFs are: (1) Total delicate pigment network; (2) peripheral delicate pigment network and central white scar-like patch; (3) peripheral delicate pigment network and central white network; (4) peripheral delicate pigment network and central homogeneous area; (5) total white network; (6) total homogeneous area; (7) total white scar-like patch; (8) multiple white scar-like patches; (9) peripheral homogeneous area and central white scar-like patch; (10) peripheral homogeneous area and central white network; and (10) atypical pattern [17]. A pigment network and a central white patch have been described as the typical appearance of common fibrous DFs [18]. DFs are thus considered non-melanocytic lesions with brown, fine, and delicate pigment network, often extending gradually toward the adjacent healthy skin. The peripheral pigment network of DFs is usually a result of hyperpigmentation of basal layer cells [19]. White scar-like patch is defined as a more or less irregularly out lined and sharply demarcated white area whose histopathologic correlation is the pronounced fibrosis within the papillary dermis [17]. However, DFs present a variety of dermoscopic patterns that may suppose difficulties in the dermoscopic diagnosis. Furthermore, to distinguish this entity from other benign or malignant tumors will only be possible with histopathologic examination in the cases of atypical or more infrequent patterns.

DFs have many histologic variants, including cellular, epithelioid, lipidized, aneurysmal, monster cell, and atypical, but the most frequently diagnosed is the common fibrous histiocytoma or common DF [11]. On histologic examination, nodular hyperpigmented DF is characterized by a nodular dermal proliferation, there is a dermal mass composed of close whorls of fibrous tissue in which there are numerous spindle or histiocytic cells [9]. The spindle cells will form focally what is referred to as a "storiform" pattern [10]. The epidermis is usually hyperplastic, hyperkeratosis, acanthosis with hyperpigmentation of the basal layer and flattened rete, which are described as "dirty feet." Most DFs are restricted to the dermis, but extension into the superficial subcutaneous fat is not uncommon [20]. "Collagen wrapping" is frequently seen, particularly at the periphery of DFs, in which spindle cells encircle collagen bundles [7], [21]. Since DF is a superficial form of benign fibrous histiocytoma, it is composed of a mixture of fibroblastic and histiocytic cells and on IHC [22]. Immunohistochemical staining may also be used to differentiate DFs from dermatofibrosarcoma protuberans [13]. Positive immunohistochemical reactions for vimentin, factor XIIla, stromelysin-3, muscle-specific actin, and CD68, as well as a negative reaction for CD34, support a diagnosis of DF [11].

A nodular hyperpigmented DF is a benign lesion that no more than a cosmetic nuisance [6]. Explaining the patient of the benign nature of DF is required. If treatment is requested, surgical excision is the method of choice [2], [23]. Cryotherapy has also been reported to be effective in selected cases, with some risk of hypopigmentation [2]. DFs should be biopsied or excised to exclude a melanocytic proliferation, a fibrosed cyst or other mesenchymal neoplasm [11]. Because these lesions are usually on the lower extremity, risks inherent to that location, such as wound separation, infection, or slower healing, 
must be considered during the post-operative care [2] Involution may occur after many years if the lesion is undisturbed, DFs usually persist, but with time may undergo partial regression, especially centrally [11].

DF has no metastatic potential. Incomplete excision or enucleation may result in a recurrence. Surgical excision under local anesthesia is usually curative [21]. Complete excision, including the subcutaneous fat, is the ideal procedure and is the mainstay of treatment with excellent prognosis [24]. With thorough excision, these lesions rarely recur, DF has very low recurrence rate ranging from $3 \%$ to $5 \%$ [8]. At the end, it is necessary to inform patients that the ultimate cosmetic outcome of DF treatment on the lower extremities may be far from optimal. Complications of DF are primarily related to surgical removal, including bleeding, infection, and scar/disfigurement [2].

Our case demonstrated two women adult patients with hyperpigmented nodule on the lower extremity. They present nodular hyperpigmented DF with classical form as a small, raised, and cutaneous nodule with a red-brown surface located on the limbs. Compression on both sides of the lesion yields dimple sign. Diagnosis established from dermoscopy and histopathological findings. Both patients perform surgically excision and have a good result with no complication or recurrence noted during the 6 months follow-up. Nodular hyperpigmented DF is one of clinical variants of DF. DF is benign fibrous histiocytoma represents one of the most common skin tumors and it has a good prognosis.

\section{Conclusion}

Dermatofibroma is benign fibrous histiocytoma that represents one of the most common skin tumours. Nodular hyperpigmented dermatofibroma is a clinical variant of Dermatofibroma which can be treated with surgical excision with good prognosis.

\section{References}

1. Kaur H, Kaur J, Gill KS, Mannan R, Arora S. Subcutaneous dermatofibroma: A rare case report with review of literature. J Clin Diagn Res. 2014;8(4):FD01-2. PMid:24959453

2. Rubenstein RM, Spohr K. Benign soft tissue tumors. In: Roenigk RK, Ratz JL, Roenigk H, editors. Roenigk's Dermatologic Surgery. $3^{\text {rd }}$ ed. United Kingdom: Informa Healthcare; 2007. p. 313. https://doi.org/10.3109/9781420019292

3. Lee W, Jung J, Won $\mathrm{CH}$, Chang SE, Choi JH, Moon KC, et al. Clinical and histological patterns of dermatofibroma without gross skin surface change: A comparative study with conventional dermatofibroma. Indian J Dermatol Venereol Leprol. 2015;81(3):263-9. https://doi.org/10.4103/0378-6323.154795 PMid:25851763

4. Hueso L, Sanmartín O, Alfaro-Rubio A, Serra-Guillén C, Martorell A, Llombart B, et al. Giant dermatofibroma: Case report and review of the literature. Actas Dermosifiliogr. 2007;98(2):121-4. https://doi.org/10.1016/ s1578-2190(07)70409-2

PMid:17397601

5. Winfield HL, Smoller B. Histiocytic lesions. In: Grant-Kels JM, editor. Color Atlas of Dermatopathology. United Kingdom: Informa Healthcare; 2007. p. 303.

6. Calonje E. Fibrohistiocytic tumor. In: Griffiths C, Barker J, Bleiker T, Chalmers R, Creamer D, editors. Rook'sTextbook of Dermatology. $9^{\text {th }}$ ed. New York, United States: Wiley; 2016. p. 137.19.

7. Elenitsas R, Chu E. Tumors of dermal origin. In: Kang S, Amagai M, Bruckner A, Enk A, Mrgolis D, McMichael A, et al., editors. Fitzpatrick's Dermatology. $9^{\text {th }}$ ed. New York, United States: McGraw-Hill Education; 2019. p. 36.

8. AIQusayer M, AIQusayer M, Alkeraye S. Unusual presentation of dermatofibroma on the face: Case report. Clin Case Rep. 2019;7(4):672-4. https://doi.org/10.1002/ccr3.2066 PMid:30997061

9. James $\mathrm{W}$, Elston $\mathrm{D}$, Berger $\mathrm{T}$, editors. Fibrous tissue abnormalities. In: Andrew's Disease of the Skin Clinical Dermatology. $10^{\text {th }}$ ed. Amsterdam, Netherlands: Saunders, Elsevier; 2011. p. 601.

10. Myers, DJ. Fillman ET. Dermatofibroma. In: Stat Pearls. Treasure Island, FL: Stat Pearls Publishing; 2021.

11. Kutzner H, Kamino H, Reddy V, Pui J. Fibrous and fibrohistiocytic proliferations of the skin and tendons. In: Bolognia J, Schaffer J Cerroni L, editors. Dermatology. $4^{\text {th }}$ ed. Amsterdam, Netherlands: Elsevier; 2018. p. 2355.

12. Bandyopadhyay MR, Besra M, Dutta S, Sarkar S Dermatofibroma: Atypical presentations. Indian J Dermatol. 2016;61(1):121. https://doi.org/10.4103/0019-5154.174131 PMid:26955137

13. Cohen PR, Erickson CP, Calame A. Atrophic dermatofibroma: A comprehensive literature review. Dermatol Ther (Heidelb). 2019;9(3):449-68. https://doi.org/10.1007/s13555-019-0309-y PMid:31338755

14. Beatrous SV, Riahi RR, Grisoli SB, Cohen PR. Associated conditions in patients with multiple dermatofibromas: Case reports and literature review. Dermatol Online J. 2017;23(9):13030. https://doi.org/10.5070/d3239036479 PMid:29469716

15. Tsunemi Y, Tada Y, Saeki H, Ihn H, Tamaki K. Multiple dermatofibromas in a patient with systemic lupus erythematosus and Sjogren's syndrome. Clin Exp Dermatol. 2004;29(5):483-5. https://doi.org/10.1111/j.1365-2230.2004.01574.x PMid: 15347330

16. Gershtenson PC, Krunic AL, Chen HM. Multiple clustered dermatofibroma: Case report and review of the literature. J Cutan Pathol. 2010;37(9):e42-5. https://doi. org/10.1111/j.1600-0560.2009.01325.x PMid:19614987

17. Zaballos P, Puig S, Llambrich A, Malvehy J. Dermoscopy of dermatofibromas: A prospective morphological study of 412 cases. Arch Dermatol. 2008;144(1):75-83. https://doi. org/10.1001/archdermatol.2007.8 PMid:18209171

18. Kelati A, Aqil N, Baybay H, Gallouj S, Mernissi FZ. Beyond classic dermoscopic patterns of dermatofibromas: A prospective research study. J Med Case Rep. 2017;11(1):266. https://doi. 
org/10.1186/s13256-017-1429-6

PMid:28927449

19. Camara MF, Pinheiro PM, Jales RD, da Trindade Neto PB, Costa JB, de Sousa VL. Multiple dermatofibromas: Dermoscopic patterns. Indian J Dermatol. 2013;58(3):243. https://doi. org/10.4103/0019-5154.110862

PMid:23723500

20. Billings S, Goldblum J. Soft Tissue Tumors and Tumor-like Reactions; 2010. p. 499-564. https://doi.org/10.1016/ b978-0-443-06654-2.00013-5

21. Alves JV, Matos DM, Barreiros HF, Bártolo EA. Variants of dermatofibroma-a histopathological study. An Bras Dermatol. 2014;89(3):472-7. https://doi.org/10.1590/ abd1806-4841.20142629

PMid:24937822

22. Monteiro R, Aithal V, Tirumalae R. Multiple eruptive dermatofibromas masquerading as cutaneous lymphoma. Indian J Dermatol. 2016;61(5):581. https://doi. org/10.4103/0019-5154.190131

PMid:27688463

23. Rashid NH, Rashid A, Goh BS, Ghani F, Saim L. Benign fibrous histiocytoma of the external auditory canal: Case report and literature review. Bangladesh J Otorhinolaryngol. 2012;18(1):77-80. https://doi.org/10.3329/bjo.v18i1.10424

24. Agarwal A. Benign fibrous histiocytoma, rare presentation: A case report. Int J Recent Sci Res. 2015;6:3962-4. 